\title{
The effectiveness of Based on acceptance and commitment therapy education on reducing loneliness among the elderly with empty nest syndrome
}

\author{
Fatollahzadeh $\mathrm{N}^{1}$, Saeedi $\mathrm{F}^{2}$, Ipchi hagh $\mathrm{S}^{3}$, Saadati $\mathrm{N}^{4}$, Rostami $\mathrm{M}^{5}$
}

\begin{abstract}
Introduction and purpose: Increased longevity, Quality of life and affects a person's ability to live independently and put him in need of the care and support of others. This study aimed to evaluate the effectiveness of Based on acceptance and commitment therapy to reduce loneliness in the elderly Empty nest syndrome was performed.

Material and Methods: The research method was quasi with pretest-posttest with control group. Study population included all patients Empty Nest Syndrome Clinic Mehravar elderly counseling center was in the summer of 2016. A total of 30 people who were eligible for the study Using judgmental sampling method chosen and two groups randomly (15 experimental and 15 controls) were replaced. 8 sessions of 90 minutes based on acceptance and commitment therapy during 2 months for the experimental group was done as a group. All participants before and after treatment, loneliness questionnaire Completed. Data were analyzed using software SPSS-22 and multivariate (MANCOVA) was used.

Findings: The results of multivariate analysis of variance (MANCOVA) showed Based on acceptance and commitment therapy had a significant effect on Loneliness $(\mathrm{P}=0.002, \mathrm{~F}=11.63)$ and Reduced in scale family $(\mathrm{P}=0.003, \mathrm{~F}=10.24)$, Emotional subscale $(\mathrm{P}=0.001, \mathrm{~F}=14.65)$ and In scale Friends $(\mathrm{P}=$ $0.01, \mathrm{~F}=13.50$ ) in Empty Nest Syndrome is among the elderly

Conclusion: The most serious danger that threatens the isolated elderly individuals taking him by those around him. In this case, a person could create an intimate and close relationship loses. Gradually alone elderly person's mental health problems. Thus the need for application-focused treatments for mood disorders And emotional loneliness of the elderly in particular a reduction is necessary.
\end{abstract}

Keywords: Acceptance and Commitment Therapy, loneliness, empty nest syndrome, elderly

Copyright $\odot 2018$ Quarterly Journal of Geriatric Nursing.This is an open-access article distributed under the terms of the Creative Commons Attribution international 4.0 International License(http://creativecommons.org/licenses/by /4.0/) which permits copy and redistribute the material, in any medium or format, provided the original work is properly cited.

1- M.A. in Clinical psychology, Islamic Azad University, Branch Rodehen, Rodehen, Iran

2 -M.A.of Psychology, Islamic Azad University, South Tehran Branch

3 -M.A. in counseling, Islamic Azad University, Branch Rodehen, Rodehen, Iran

4- Ph.D. student in counseling, Islamic Azad University, Branch Isfahan (Khorasgan), Isfahan, Iran

5- PhD student of counseling, Islamic Azad University, Branch Science and Research, Tehran, Iran

Email:Mehdi.rostami25@gmail.com 


\section{اثربخشى گَروهى آموزش درمان مبتنى بر يذيرش و تعهد بر كاهش احساس تنهايى در سالمندان با سندرم آشيانه خالى تئى}

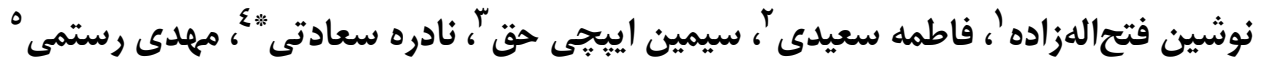

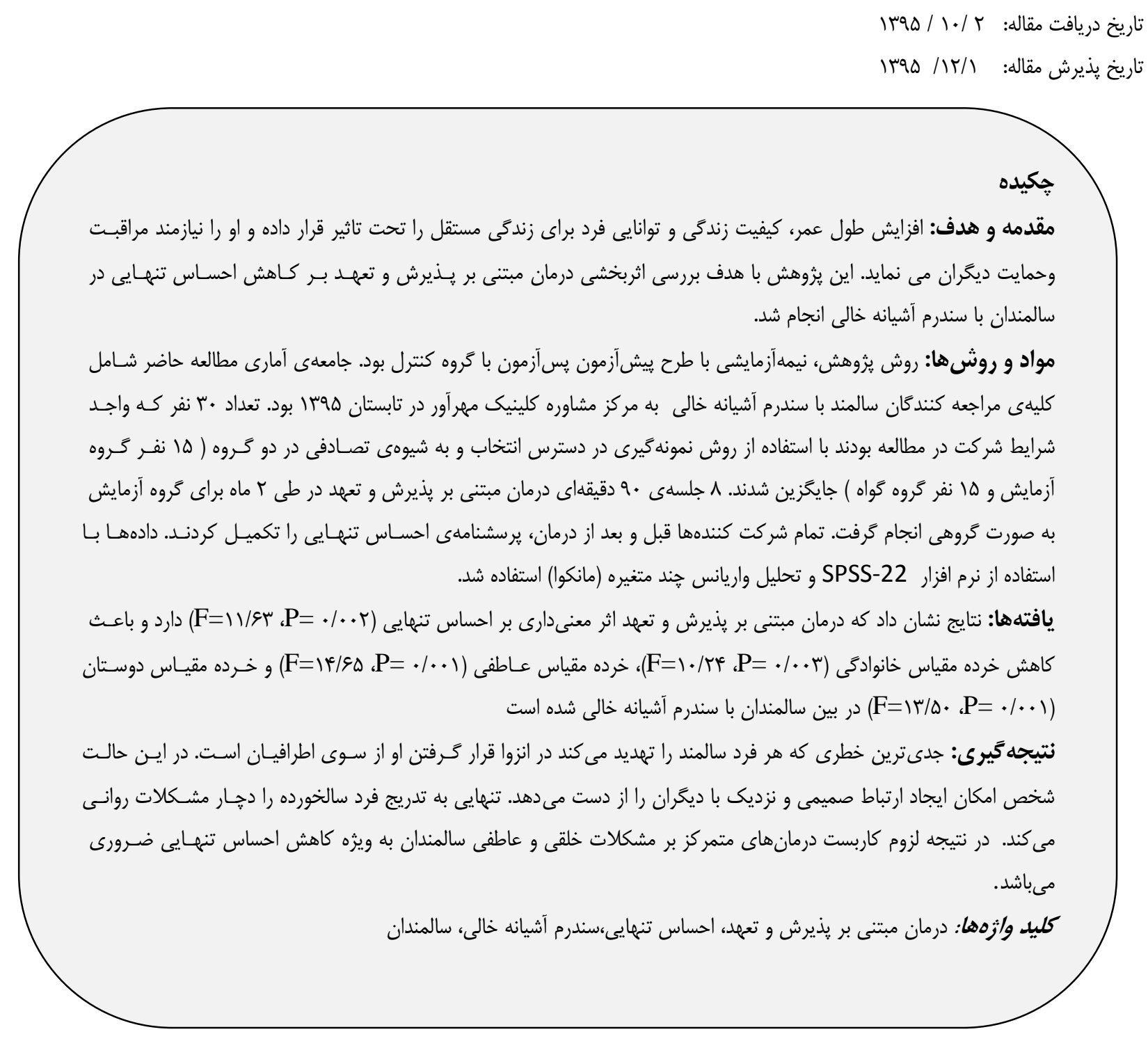

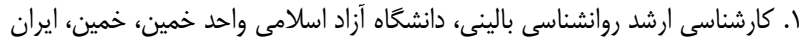

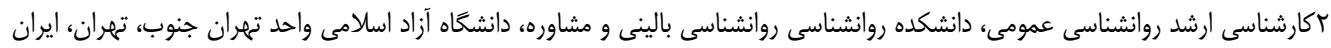

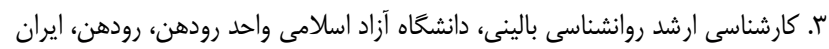

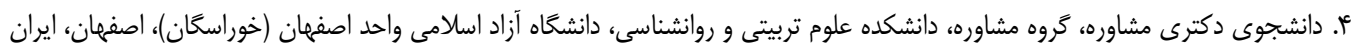
(نويسنده مسؤول). پِست الكترونيكى: dr.nsaadati@gmail.com ه. دانشجوى دكترى مشاوره، كَروه مشاوره، دانشكده علوم انسانى و اجتماعى، دانشخاه آزاد اسلامى واحد علوم و تحقيقات تهران، تهران، ايران 
افزون بر آن، اهميت خانواده بــه انــازهاى اسـت كـه سـلامت و بالندگى هر جامعه وابسته به سلامت و رشد خانواده در آن اسـت. هر خانواده وضعيت و فضاى عاطفى منحصر به فـرد دارد و روش اداره و نوع عملكرد آنها با يكديخر متفــاوت اسـت، بـراى همـين دانشمندان و صاحبنظران تقسيه بندى هاى مختلفى از خانواده ارائه مىدهند (T) تعاملات درون خانواده يكى از مهمترين عوامل تعيين كننده سلامت روانى است. ممكـن اسـت عـواملى در راه انـدازى علائم و تسهيل بروز افسردحى دخيل باشـند كـهـ از دسـت دادن ساير اعضاى خانواده و دوستان و تجربئه فقـدان از جملـهى ايـنـ عوامل است (ه). به محض آنكه فرزندان خانه را بدرود مى گَينـــ زن و شوهر سعى مى كنند به زندگى يا روابط خود معنا بدهند. در اين دوره برخى ناراحتى ها و حتى استرس منفى تجلى مس كنــــ كه تحت عنوان "سندرم اشيانه خالى" يا "سندرم اشيانه متـروى"

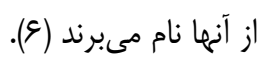

يكى از بديدههاى سنين ميانسالى، سندرم آشيانه خالى ناميده مى شود و نوعى افسردحى است كه پِ از آنكه آخرين فرزند خانه را تـرك كـرد در زن و مـرد ايجـاد مسى شـود. در ايـن دوره اخـر فعاليتهايى انجام نشود ممكن است يدر و مادر افسرده شوند (V). در الخَوى مرحلهاى Duvall هرخــه هـاى زنــدَى خـانوادگىى، تحول متعارف يك خانواده كامل و تمام عيار -منظور خانواده اى است كه يدر و مادر هر دو در آن حضور دارنـد- در قالـب هشـت مرحله صورت مى گيرد، كه اين مراحل با ازدواج شروع مىشوند و با مرگ دو همسر به پايان مىرسند كه دوره آشيانه خالى مرحلـه. ششم مى باشد؛ كه البته اين مراحل تا حدودى دلبخواهى است و
افزايش هشمخير جمعيت سالمند در سراسر دنيا بِيده اي است كه از قرن بيستم آغاز شده است. سازمان ملل در سـال \&.. ب تعـداد كل سالمندان دنيا را حدود V ميليـون نفـر بــرآورد كـرده اسـت و ييشبينى مىشود كه اين جمعيت در • + سال آينده دو برابر شود (). طبق گزارش سازمان بهداشت جهانى اميد به زندگى در ايران، در مردان VV سال و در زنان ايرانسى لVـال اسـت كـه نشـان مىدهد آمار سالمندان ايرانى نيز رو به افزايش است و جامعسه در آينده در برابر مسائل جدى مربوط به سالمندان و حـل مشـكلات أنها قرار خواهد كَرفت. بنابراين سالمندى و شرايط ويـزّى افـراد

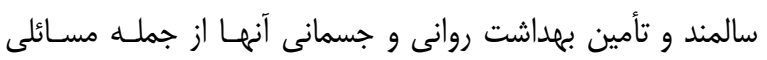
است كه توجه ويزةاى را مى طلبد (1). عوامل فردى مانند سن، جنس، نـرزاد و ويزَّى هـاى اجتمـاعى و فرهنگى و اقتصادى در زمان و ميزان سالمندى تأثيركــار اسـت. تغييرات ايجاد شده در دوران سالمندى شـامل مسـائلى همجــون كاهش توانايىهاى فيزيكى، تغيير پاسخ بلن به داروها، تجربـهى

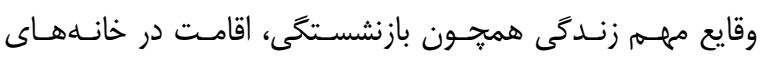
سالمندان و كاهش درآمد (T)، كم شدن موقعيتها براى برقرارى ارتباطهاى اجتماعى، از دست دادن حمايت اجتماعى و مشـاركت كمتر در جامعه (سا) و از دست دادن استقلال كه تأثير عميقى بـر

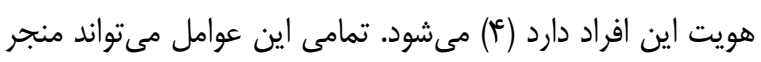
به ايجاد احساس تنهايى در سـالمندان شـود. از طرفى، افـزايش روزافزون جمعيت سالمندان و از طرف ديخـر، تغييـرات اجتمـاعى اقتصادى و شيوهى زندگى فردى و خانوادگى باعث افزايش تعداد مؤسسات نحَمدارى سالمندان شده است. 


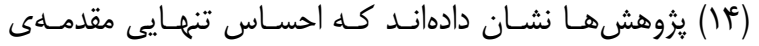
افسردگى و فراموشى است (ها) و ادامـهى حيـات را تحـت تـأثير

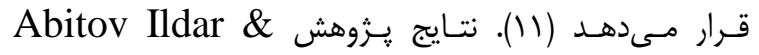
Gorodetskaya سالمندان زندگى مى كنند از احساس تنهـايى بيشـتر و سرسـختى روانشناختى كمترى نسبت به سالمندان ساكن در محـيط خـانواده برخوردارند. نتايج يزوهش Werner \& Dimitris داد كه سالمندان جينى ساكن در سراى سالمندان احساس تنهايى زيادى را تجربه مى كنـــــ و عملكـرد و حمايست خـانواده ميتوانـــ احساس تنهايى آنها را كاهش دهد. Luo \& Waite (NI) نيز در يزوهشى نشان دادند كه افراد سالمند احساس تنهايى بيشترى دارند كه ميتوان با شـركت در فعاليتهـاى اجتمـاعى، برنامـهـــاى فردى در اوقات فراغت و انجـام ورزش احسـاس تنهـايى آنهـا را كاهش داد. نتايج يروهش Alpass \& Neville (19) نشـان داد كه احساس تنهايى در بين افراد ساكن خانسهى سـالمندان بـهـ طور معنى دارى بيشتر از سالمندانى است كه با اعضاى خـانوادهى

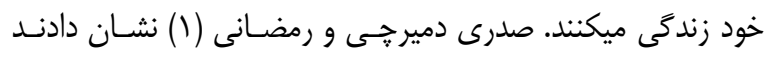
آموزش درمان وجودى باعث كاهش احسـاس تنهايى و اضـطراب مرى در سالمندان شده است. همجنـين خالـديان و همكـاران (V) نشان دادند كه آموزش گروهى درمان شناختى رفتارى بـر كـاهش افسردگى و افزايش اميد به زندگى در سالمندان بـا سـندرم آشـيانه خالى موثر بوده است. همجنين خالديان و سهرابى (T) در يزوهشى ديخر نشان دادند كـهـ آمـوزش كروهـى معنـا درمـانى بـر كـاهش افسردكى و افزايش اميد به زندكَى در سالمندان بـا سـندرم آشـيانه

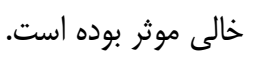

اين الكوى هشت مرحلـهاى از Duvall اسـت (^). از ايـن رو، وظيفه درمانكر آن است كه به خانواده كمى كند تا بحران (آشيانه خالى)، را به كمك يكديخر برطرف سـازند، و از ايـن طريـق بــهـ توازن جديدى دست يافته و با سـاخت خـانوادَى جديــ خـويش منطبق شوند. اگر خِنين جيزى تحقق يابد، خـانواده مجــداً سـير تحولى خود را به بيش خواهد برد و ممكن است غيبت فرزندان در خانه باعث افزايش تعارضات زناشويى گردد، يا به خاطر احسـاس يوجى و فقدان معنا در زندگَى، به آنها حالت افسـردگى و تنهـايى. دست دهد (9). بنظر كارتر و مك گكلدريك (بـهـ نقـل از ؟) وقتى فرزندان خانه را ترك مى گويند، احساس نوميدى در والـدين آنهـا بالا مىرود. در سالمندان بعد از علل جسمانى، احسـاس تنهايى و افسردحى دومين علت ناتوانى برآورد شده است. نتايج يثوهشهـا در ايران نشان داد يك سوم مراجعان سريايى سالمندان به مراكز درمانى از اختلالات روانى رنج مىبرند و شايعترين اختلال روانى

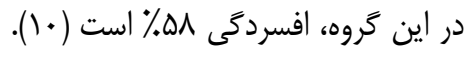
افزون بر آن، احساس تنهايى سالمندان يكى از مشكلات روانى و اجتماعى است كه كمتر به آن توجه شـده اسـت. كـاهش قـواى جسمى و سلامتى و فوت نزديكان، سالمندان را در خطر انزوا قرار مىدهد و تنهايى در اواخر عمر براى بسيارى از آنان ناخوشـايند و فرساينده است (I). شيوع احساس تنهايى در بين سالمندان از r تا • ا درصد گزارش شده است (11) بسيارى از سالمندان دورهى ييرى را به عنوان دورهى تنهايى توصيف كرده و از آن به عنـوان يك تجربلى ناخوشايند و ترسناك ياد مى كنند (זI). بنابراين بـــ نظر ميرسد كه اين مقوله به توجه خاصى نياز داشته باشـــ (سا). علاوه برآن، يذيرفته نشدن از سوى ديخران و انزواى اجتماعى از علل مهر بيمارىهاى روانى در سنين سالمندى به شمار مىرونـــ 
روانى فرد در مورد تجارب ذهنى (افكار و احساسات) افزايش يابد و متقابل آن، اعمال كنترلى نامؤثر كـاهش يابـــ. بــه بيمـار آموختـهـ مىشود كه هر گونه عملى جهت اجتناب يـا كنتـرل ايـن تجـارب ذهنى ناخواسته بىاثر است يا اثر معكوس دارد و موجب تشديد آنها مىشود و بايد اين تجارب را بدون هيجَّونـهـ واكـنش درونسى يـاـ بيرونى جهت حذف آنها به طور كامـل يـذيرفت. در قـدم دوم بـر آكَاهى روانى فرد در لحظهى حال افزوده مىشود؛ يعنى فرد از تمام حالات روانى، افكار و رفتار خود در لحظهى حال آَّاهى مىيابد. در

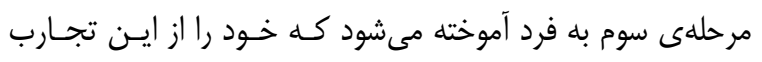
ذهنى جدا سازد (جداسازى شناخت)، به نحوى كه بتواند مستقل از اين تجارب عمل كند. جهارم تلاش براى كاهش تمركز مفرط بـر خود تجسمى داستان شخصى (مانند قربانى بودن) كه فـرد بـراى خود در ذهنش ساخته است. يـنجم، كمـك بـه فـرد تـا ايـن كـهـ ارزشهاى شخصى اصلى خود را بشناسد و به طور واضح مشخص سازد و آنها را به اهداف رفتارى خاص تبديل كنــ (روششناسى ارزشها). در نهايت، ايجاد انكَيزه جهت عمل متعهدانه يعنى فعاليت معطوف به اهداف و ارزشهاى مشخص شده بــهـ همـراه ٍـــيرش تجارب ذهنى. اين تجارب ذهنى مىتوانـــ افكـار افسـرده كنـــه، وسواسى، افكار مرتبط به حوادث (تروما) و هراس ها باشـند (سب و

با توجه به اينكه يزوهشهاى حندانى در زمينه سندرم آشيانه خالى كه يكى از هشت مرحلهى جرخه هاى زندگى خانوادگى مى باشد صورت نخَرفتـه هـــف از يـروهش حاضـر اثربخشى درمـان (V) كروهى مبتنى بر يذيرش و تعهل بر كـاهش احسـاس تنهايى در سالمندان با سندرم آشيانه خالى مى باشد و جهت ياسخگَويى بـهـ اين سئوال به اجرا درآمد: كه آيا درمان گروهى مبتنى بر يذيرش و
از ايـن رو، درمانهـاى مختلفى در زمينـهى بهبـود وضـعيت روانشناختى سالمندان اجرا گرديده است از جمله ميتوان به واقعيت درمانى، معنادرمانى، و درمان شناختى رفتارى اشاره كرد. از جملـهـ درمانهاى ديگرى كه ميتواند در زمينهى بهبود سلامت روانى و غنى سازى زندكى سـالمندان تأثير گَذار باشـد، درمـان مبتنـى بـر يذيرش و تعهد است. درمان مبتنى بــر يـــيرش و تعهـــ يكسى از الكَوهاى درمانى بسط يافتهى اخير است كـه فراينـدهاى درمـانى كليدى آن با درمان شناختى رفتارى-سنتى متفاوت است و اصول زيربنايى آن شامل (1) يذيرش يا تمايل به تجربهى درد و يا ديخر رويدادهاى آشفته كننده بدون اقدام به ممار آن و (r) عمل مبتنى بر ارزش يا تعهد توأم با تمايل به عمل به عنوان اهداف معنى دار شخصى بيش از حذف تجارب ناخواسته است كه در تعامل با ديخر وابستخى هاى غير كلامى منجر به كاركرد سالم مىشود. اين روش شامل تجربيات تجربى و تمرينات مبتنى بر مواجهه، استعارههـاى زبانى و روشهايى جون آموزش مراقبت ذهنى است (·r). يذيرش و تعهد درمانى در سال عيو1 توسط Hayes ايجاد شد. اين روش قسمتى از موج سوم درمانهاى رفتارى است و به دنبال موج دوم اين درمانها از قبيل درمان شناختى رفتارى يديـــ آمــد. يذيرش و تعهد درمانى با يــ برنامـهى تحقيقى تحـت عنـوان نظريهى نظام ارتباطى در ارتباط است. آشكارا اين رويكـرد تغييـر كاركرد افكار و احساسات به جاى تغيير شكل، محتوا يا فراوانى آنها را مى يذيرد (آT) هدف اصلى، ايجاد انعطافيذيرى روانسى اسـ، يعنى ايجاد توانايى انتخاب عملى در بين گز ينههـاى مختلـف كـهـ متناسبتر باشد، نه اين كـه عملى تنهـا جهـت اجتــاب از افكـار، احساسات، خاطرهها يا تمايلات آشفتهساز انجام يا در حقيقـت بـهـ فرد تحميل شود (Tr). در اين درمان ابتدا سعى مىشود تا يذيرش 
شدند سيس در دو حَروه آزمـايش (ها نفـر) و حـواه (ها نفـر) بــهـ

صورت تصادفى كاربندى شدند. كَروه آزمـايش ^ جلسـهـ آمـوزش

مبتنى بر يذيرش و تعهلد به شيوه گروهى را دريافت كردنـد، امـا

كروه گَواه مداخله اى را دريافت نكردند. جهت تحليل داده هـا از آمار توصيفى و آمار استنباطى (آزمون تحليل واريانس هُند متغيره)

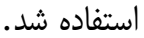

مقياس احساس تنههايى. ساخت و اعتباريابى مقيـاس بـراى اولين بار توسط دهشيرى در بين دانشجويان ايرانى صورت كرفته است. اين مقياس داراى سه عامل تنهايى ناشى از روابط خانوادگى ( عا سؤال)، تنهايى ناشى از ارتباط بـا دوسـتان ( لا سـؤال) و نشانههاى عاطفى تنهايى (I سئوال) تشكيل شده است و در كل ^r سؤال دارد. مقياس احساس تنهايى و سه خرده مقيـاس آن از همسانى درونى قابل قبولى برخوردار است. ضرايب آلفاى كرونباخ براى كل مقياس (9/×، و خـرده مقيـاسهـاى تنهـايى ناشـى از

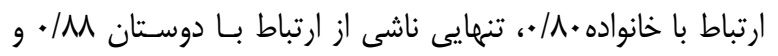
نشانههاى عاطفى تنهايى V9/• است. اعتبار بازآزمايى مقيـاس در مورد Y نفر از دانشجويان با فاصلهى زمانى دو هفته بـراى كـل مقياس ع /A/، خرده مقياسهاى تنهايى ناشى از ارتباط با خانواده

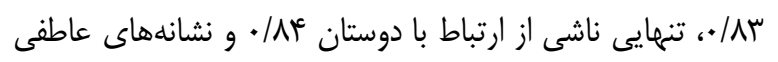
تنهايى V9/ • بوده است. اين ضرايب بيانكر ثبات نمرات مقيـاس تنهايى در طول زمان است (كه). نمرهذارى با استفاده از مقياس ليكرت ه درجهاى (طيف • تأ ) صورت مى از سؤالات خيلى زياد نمرهى صفر، زياد ا ، متوسط ك، كمّ بّو خيلى كم أ مى گيرد و براى گـروه ديخـرى از سـؤالات بـهـ طـور معكوس نمرهكذارى مىشود. نقطهى برش يرسشنامه VV مىباشد كه نمرات بالاتر از Vو نشان دهندهى وجود احسـاس تنهـيى در
تعهد بر كاهش احساس تنهايى در سالمندان با سندرم آشيانه خالى موثر مى باشد؟ بنابر آنجه ذكر گرديد اين يـرُوهش درصـدد اسـت طى فرايندى علمى روى دوَّروه كَواه وآزمون، با استفاده از روش درمانى گَروهى مبتــى بـر یـــيرش و تعهــد، احسـاس تنهـايى در سالمندان با سندرم آشيانه خالى را در مراجعـه كنــدكان بـه مركـز مشاوره مهر آور تهران مورد مطالعه قرار دهد.

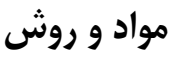

طرح اين يُوهش، نيمه آزمايشى از نوع ييش آزمون ِس آزمون با كروه كواه است. در اين يزوهش جامعه آمـارى را كليـه مراجعـه كنندًان به مركز مشاوره مهرآور منطقـه ل| تمهران شـامل مسى شوند. از بين كليـه سـالمندان مراجعـه كنــــه بــه مركـز مشـاوره، سالمندانى كه واجد شرايط بودند و با توجه به ملاكىهـاى ورود بــــ يزوهش: فرزندانشان آنها را ترك كرده اند و از آنها جدا شـده انـد، عدم تشخيص در يكى از محورهاى راهنمـاى تشـخيص آمـارى اختلالهاى روانى، عدم دريافت داروهاى روانيزشكى براى مـدت بيش از دو هفته قبل از شروع مداخله، عدم شـركت همزمـان در برنامهى درمانى ديگر، داشتن سواد خوانـدن و نوشـتن، و كسـب نمرهى بالاتر از يا برابر با نقطـهـى بــرش يرسشـنامهى احسـاس تنهايى بود. افراد داراى شرايط فوق و مايل به همكارى با كسـب رضايتنامه كتبى وارد يزوهش شدند. از جمله ملاكهـاى خـروج، عدم تمايل به ادامهى درمان و عدم مشاركت و همكارى در فرايند اجراى درمان و غيبت بيش از دو جلسـه در جلسـات درمـان بـود. يس از بررسىهاى ابتدايى و مصاحبههـاى صـورت گرفتـه از بـين مراجعه كنندًان واجد شرايط • ب سالمند به صورت هدفمند انتخاب 
طى ^ جلسه •و دقيقـهاى در ^ هفتـأَ يِيـايى مـورد مداخلـه قـرار كرفتند كه خلاصُٔ محتواى هر جلسه در جدول ا ارائه شده است.
افراد است. طرح درمانى يذيرش و تعهلد. در ايـن يـزوهش سالمندان بر اسـاس بسـتهى آموزشـى كتـاب درمـانى مبتنـى بـر يذيرش و تعهد ايزدى و عابـدى (ז) و Dahl و همكـاران (Kع)

جدول ا - خلاصه محتواى طرح درمانى يذيرش و تعهد

\begin{tabular}{|c|c|}
\hline 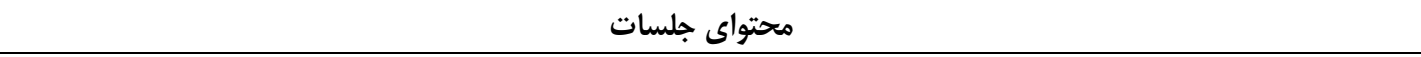 & 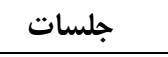 \\
\hline برقرارى رابطه درمانى، آشنا نمودن افراد با موضوع يُوهش، ياسخ به يرسشنامه و بستن قرارداد درمانى. & جلسه اول \\
\hline كشف و بررسى روشهاى درمانى و ارزيابى ميزان تأثير آنها، بحث در مورد موقتى و كم اثر بودن درمانها با استفاده از تمثيل، دريافت بازخورد و ارائه & 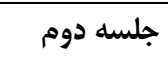 \\
\hline \multicolumn{2}{|l|}{ تكليف. } \\
\hline \\
\hline \multicolumn{2}{|l|}{ استفاده از تمثيل، دريافت بازخورد و ارائه تكليف. } \\
\hline \\
\hline \multicolumn{2}{|l|}{ آرامى، دريافت بازخورد و ارائه تكليف. } \\
\hline \multicolumn{2}{|l|}{ معرفى مدل رفتارى سهبعدى بلمنظور بيان ارتباط مشترك رفتار الحساسات، كاركردهاى روانشناختى و رفتار قابل مشاهده و بحث در مورد تلاش براى } \\
\hline \multicolumn{2}{|l|}{ تغيير رفتار بر اساس آن، دريافت بازخورد و ارائه تكليف. } \\
\hline \multirow{2}{*}{\multicolumn{2}{|c|}{ 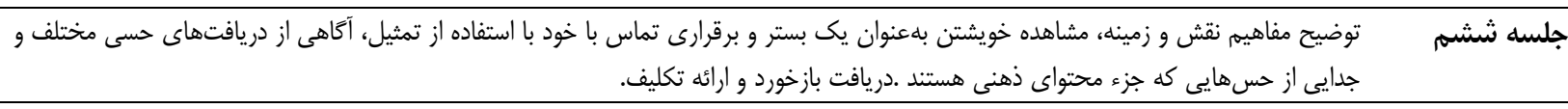 }} \\
\hline & \\
\hline توضيح مفهوم ارزشها، ايجاد انكيزه براى تغيير و توانمند نمودن مراجع براى زندكى بهتر، تمرين تمركزى، دريافت بازخورد و ارائه تكليف. & جلسه هفتم \\
\hline آموزش تعهد به عمل، شناسايى طرحهاى رفتارى مطابق بارزشها و ايجاد تعهد براى عمل به آنها، جمعبندى جلسات، اجراى پِسآزمون. & جلسه هشتم \\
\hline
\end{tabular}

شركت كنندكًان آزاد بودند كه در صورت عدم تمايـل بـه ادامـهى درمان، جلسات را ترك كنند. همجنين به دليل مسـائل اخلاقى و همجنين انخَيزه حضور در يُوهش به كَروه كَواه تعهد داده شد كـهـ در جلسه توجيهى روش درمان و اهداف يزوهش حاضر به صـورت يس از پايان جلسات درمانى گروه آزمايش، آنها نيز تحت آموزش كلى براى مراجعان توضيح داده شد. پِ از مصاحبه و غربالحَرى از

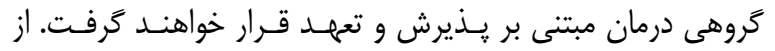
آزمون تحليل واريانس جند متغيره (مانكوا) براى تجزيه و تحليـل بين مراجعان واجد شرايط • ب نفر به شيوهى در دسـترس هدفمنـــ انتخاب و پس از آن در دو گروه گَواه و آزمايش به صورت تصادفى دادها استفاده شد. دادهها با استفاده از نرمافزار SPSS نسـخهى

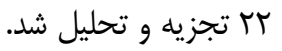

\section{يافتهها}

در يزوهش حاضر ميانكَين سنى شركت كنندكان در هـر دو كـروه

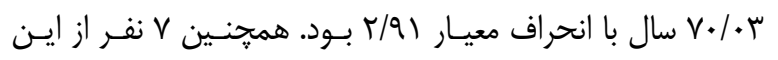
شركت كنندكان (س/سץ\%) داراى مدرك تحصيلى زيـر ديـيله، 11 جايخزين شدند. قبل از آغاز جلسات اصلى درمان، جلسهاى بـراى كروه آزمايش تشكيل شد و در اين جلسـه تمـام قواعـد و قـوانين ضرورى گروه توضيح داده شد. در اين جلسه سعى شد تا حـدودى افراد با هم تعامل داشته باشند و با هم صحبت كنند تـا اضـطراب اوليهى ورود به كروه در آنها كاهش يابد. درمان مبتنى بر يذيرش و تعهد ( 1 جلسه) هفتهاى يك جلسـهى •9 دقيقـهاى بـراى گَروه آزمايش اجرا شد. بـه دليـل رعايـت اصـول اخـلاق در يـروهش، 
همجنين در جـدول (با و أ) نتـايج تحليـل واريـانس جنـــ متغيـره

(ACT) (مانكوا) تأثير آموزش درمان مبتنى بر يذيرش و تعهـد (ACT)

بر ميزان نمرات احساس تنهايى و خـرده مقيـاسهـايش در كَروه

آزمايش و كَواه در ييش آزمون و پِسآزمون را نشان مىدهد.

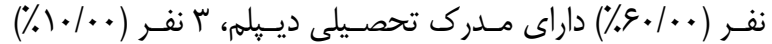

داراى مـدرى كـاردانى و r نفـر (V/\&\%) داراى مــدرى تحصـيلى

ليسانس مىباشند. جدول (T) ميانگين و انحراف استاندارد نمرههاى

آزمودنى هاى گروه آزمايش و گَواه را در متغيـر احسـاس تنهـايى و

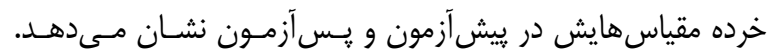

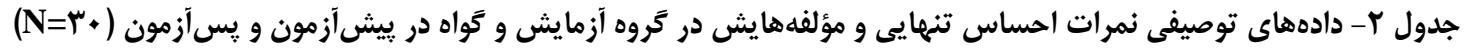

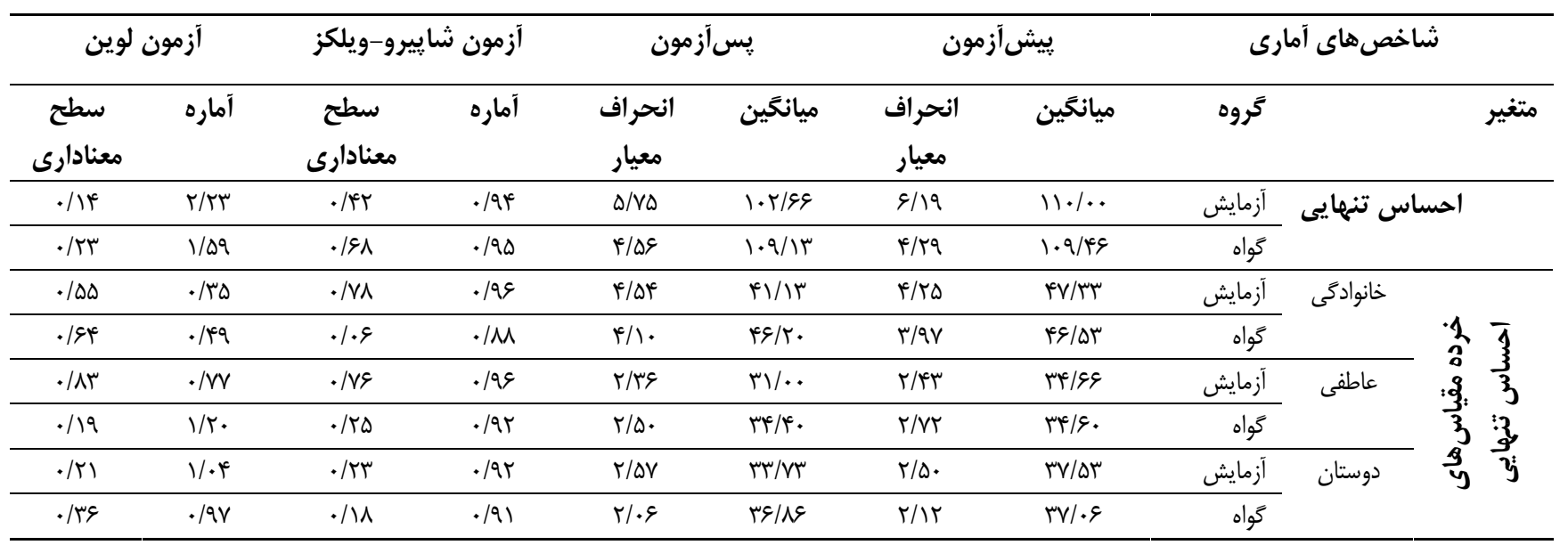

مرحله يِيش آزمون و پِ آزمون تفاوت معنادارى مشاهده مى شود. همجنين نتيجه آزمون شاييرو ويلكز حاكى از برقرارى شرط توزيع طبيعى نمرهها و نتيجه آزمون لوين نيز نشان دهنده برقرارى شرط همسانى واريانسها در متغيرهاى يزوهش (احساس تنهايى و خرده مقياسهاى آن) است.
با توجه به جدول r، نمرات احساس تنهايى گروه آزمايش از نمرات احساس تنهايى در يِآزمون كاهش يافته اسـت. ولـى در نمـرات

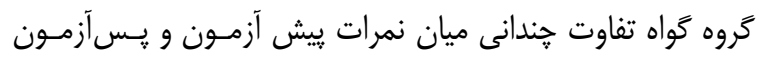
مشاهده نمىشود. همخِنين نمرات خرده مقيـاسهـاى خـانوادگى، عاطفى و دوستان نيز در كروه آزمـايش نسـبت بــهـ كَروه كَواه در

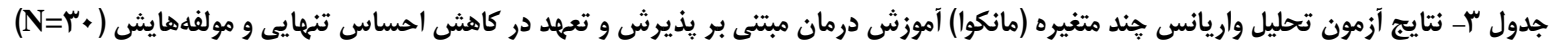

\begin{tabular}{|c|c|c|c|c|c|c|c|c|}
\hline آزوان & (اندازه اثر) & معنادارى سطح & توزيع لؤل df & فرضيه df & أمار F & ارزش & اثر & \\
\hline $1 / \cdot \cdot$ &.$/ 99$ &.$/ \ldots$ & $r \Delta$ & r & HАQT/TF &.$/ 99$ & اثر يِيلايى & مقدار \\
\hline $1 / \cdot$ &.$/ 99$ & $\cdot / \cdots$ & ro & r & rМqY/TF &.+.4 & لانداى ويلكز & ثابت \\
\hline $1 / \cdot \cdot$ &.$/ 9 T^{\circ}$ & $\%$ & ro & r & $11 / 4$ & $\cdot /\left.4\right|^{\circ}$ & اثر يِلايى & تروه \\
\hline $1 / \cdot \cdot$ &. $\mid a y^{2}$ &.$/ \ldots$ & ro & r & $11 / \pi 4$ & $\cdot / \pi \Delta$ & لانداى ويلكز & \\
\hline
\end{tabular}




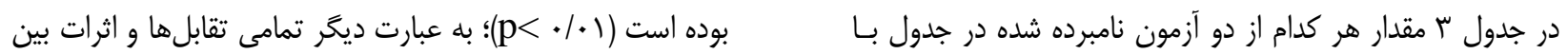

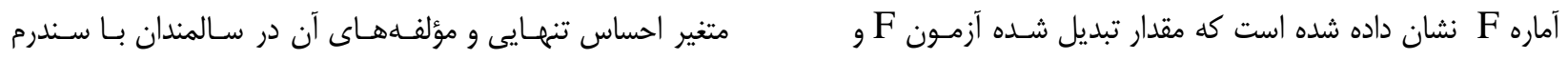
يك توزيع تقريبى از آن مىباشد. بر اساس مقادير جدول فوق اثر آشيانه خالى در مدل معنادار بوده است. تمامى آزمونهاى نامبرده شده در سطح كوخىتر از 1 ـ/ معنادار

جدول ع- نتايج تحليل واريانس جند متغيره (مانكوا) براى بررسى اثربخشى آموزش درمان مبتنى بر يذيرش و تعهد بر كاهش احساس تنهايى و مولفههايش $(\mathrm{N}=\mathrm{r}+)$

\begin{tabular}{|c|c|c|c|c|c|c|c|c|}
\hline آز توان & ضريب انازه اثر & معنادارى & F آماره F F & ميانگين مجذورات & درجه آزادى & مجموع مجذورات & متغيرها & \multirow{5}{*}{ مقدار ثابت } \\
\hline $1 / \cdot \cdot$ &.$/ 99$ &.$/ \cdots$ & ITEVE/T. & . & 1 & TMEATE/T. & احساس تنهايى & \\
\hline $1 / \cdot$ &.$/ 99$ & $\%$ & $r \cdot \mu \varphi / T V$ & $\Delta V T \cdot r / r r$ & 1 & $\Delta V T \cdot r / r r$ & خانوادگى & \\
\hline $1 / \cdot$ &.$/ 99$ &.$\cdots$ & DFTr/ar & rT.VN/V. & 1 & Tr.VN/V. & عاطفى & \\
\hline $1 / \cdot \cdot$ &.$/ 99$ &.$/ \cdots$ & SNDS/TI & rVRیr/v. & 1 & rVrیr/V. & دوستان & \\
\hline$\cdot / 9$. & $\cdot / 49$ & $\% r$ & $11 / 94$ & 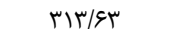 & 1 & 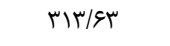 & احساس تنهايى & \multirow{4}{*}{ تروه } \\
\hline$\cdot / \wedge V$ & ( & $\% r$ & $1 . / \pi F$ & $19 r / \Delta \%$ & 1 & $19 \% / \Delta 4$ & خانوادگى & \\
\hline$\cdot / 90$ & $\cdot / \mu f$ &.+.1 & $\mid F / 90$ & $\Lambda \varepsilon / v$. & 1 & $\Lambda \varepsilon / v$. & عاطفى & \\
\hline \multirow[t]{9}{*}{$\cdot / 94$} & r &.+.1 & $1 \pi / \Delta$. & $V H / G r$ & 1 & $V r / g r$ & دوستان & \\
\hline & & & & rq/a & ru & $V \Delta \Delta / \cdot 9$ & احساس تنهايى & \multirow{4}{*}{ خطا } \\
\hline & & & & $1 N / v q$ & $r \Lambda$ & DTE/II & خانوادگى & \\
\hline & & & & Q/9) & $r \Lambda$ & $\mid \varepsilon \Delta / \varepsilon$. & عاطفى & \\
\hline & & & & $\Delta / \& \Delta$ & rᄉ & $10 Y / 99$ & دوستان & \\
\hline & & & & & r. & rTVDIT/.. & احساس تنهايى & \multirow{4}{*}{ كل } \\
\hline & & & & & r. & DVQTr/.. & خانوادگى & \\
\hline & & & & & r. & . & عاطفى & \\
\hline & & & & & r. & rVs.q/.. & دوستان & \\
\hline
\end{tabular}


Alpass , (IV)Luo \& Waite (I) \& D Dimitris (1) \& Neville

در تببين يافتههاى يزوهش ميتوان كفت تمايل براى صميمت بين فردى با هر انسانى از زمان تولد تا مرگ وجود دارد و هيج انسانى نيست كه به دليل از دست دادن آن مورد تهديد قرار نخَيرد. انسان با نياز به ارتباط و صميميت متولد ميشود (I).. هنـريش و كَالن (צץ) معتقدند هستهى اصلى بيشتر اختلالهاى عـاطفى، احسـاس انزوا و تنهايى است. اين امر به خصـوص در افـراد سـالمند نمـود بيشترى دارد. آدميان موجودات اجتماعى هسـتند و بــه يشـتيبانى آرامش و اطمينان خاطرى كه در همكارىهاى گروهـى از جانـب ديخران فراهم ميشود نياز دارنــــافـزون بـر ان، از طريـق بيـان نغرانيهاى خود در گروه غالباً ميتوانيم مشكلات خـود را واضـحتر بيينيه. كروه درمانى سالمندان فرصتى است براى حمايت متقابل و وسيلهاى است براى كمك به بيمار براى مقابلهى مؤثر با اسـترس و سازش با منابع كاهندهى زندگى ((). اعضاى گـروه رفاقتهاى تازهاى را در زمان فقدان دوسـتان قـــيم و بـالا بــــن احتـرام و اعتماد به نفس يبدا ميكنند (TV) سالمندان در اين شرايط ميتوانند معناى مناسبى در زندكى بيابند، واكـنش خـويش را آزادانـه بــراى

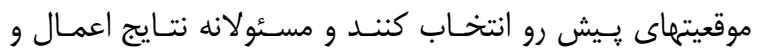
انتخابهاى خود را بيذيرند. در اين فرايند آنها متوجه ميشـوند كـهـ رنج دورى از فرزندان و طرد شـدن از سـوى آنهـا، غـمه و انـدوه، كمبودها، بيماريها و مشكلات جسمانى اجتناب نايذير است و فقط يك فرصت باقى ميماند كه در اين موقعيت شيوهى نخرش و طرز برخوردشان با مشكل و تحمل مصائب را تغيير دهند، با معنا دادن به رنجها و دردها بر از دست رفتهها تمركز نكنند و بـا توجـه بــه كذرا بودن زندگىى، وقت، عمر و امكانـات خـود را صـرف كيفيـت
جدول ع آزمونهاى اثرات درون آزمـودنىهـا، مهـمتـرين نتـايج آزمون تحليل واريانس جند متغيره را شامل مىشود. اين جـدول، آزمونهاى جند متغيره براى عاملهاى درون آزمودنىها و روابـط تقابلى بين آنها را نشان مىدهد. همانطور كه مشاهده مى كنيـد

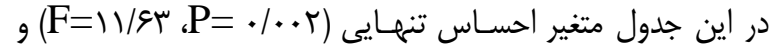

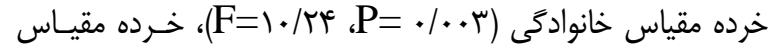

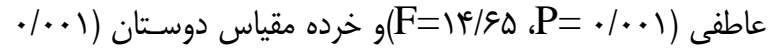

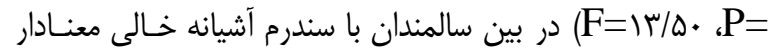
بوده است؛ بنابراين نتيجه كرفته مى شود كه آموزش درمان مبتنى بر يذيرش و تعهد بر كاهش علائم احساس تنهايى و مولفهــايش در كروه آزمايش اثر كذاشته است.

\section{بحث و نتيجه كيرى}

هدف از يزوهش حاضر بررسى اثربخشى درمان مبتنى بر يذيرش و تعهد بر كاهش احساس تنهـايى در سـالمندان بـا ســدروم آشـيانه خالى بود. نتايج يثوهش نشان داد كه بين ميـانخَينهـاى تعـديل شدهى گروه آزمايش و كنترل در يـسـآزمـون از لحـاظ احسـاس تنهايى و مولفههايش تفاوت معنادارى وجود دارد. بدين صورت كه درمان مبتنى بر يذيرش و تعهد باعث كاهش قابل ملاحظـهاى بـر احسـاس تنهـايى و مولفـهــايش در گَرووه آزمـايش شـده بـود. يافتهاى يزوهش حاضر با نتايج يزوهشهـاى صـدرىدميرجى و رمضانى (I)، خالديان و سـهرابى (()، خالـديان و همكـاران (V)، Werner ،(1ه) Abitov Ildar \& Gorodetskaya 
احساس منحصر بــهـ فـرد بـودن در زمينـه مشـكلات و احسـاس تنهايى خود دارند. اين احساس منحصر به فرد بودن باعث تشديد انزواى اجتماعى سالمندان مى گردد و انـزواى اجتمـاعى احسـاس منحصر به فرد بودن را در آنها تقويت مى كند (I). درمان گروهى به سهولت اين امكان را فراهم مى سازد كه تعدادى از اين افـراد در يك مكان جمع شده، با يكديخر رابطه برقرار كنند و راجع بـه مشكلات مشابه خود به كَفتكو بنشينند. از بين رفتن اين احساس انحصار نه تنها باعـث آرامـش و راحتـى افـراد ميشـود بلكـهـ بـهـ توسعهى روابط آنها در خارج از محيط درمـانى كمـى مس كنـــ ضمن اينكه اعضاى تروه در جريان تعامـل، بـهـ يكـديكر كمـى مى كنند، يعنى در جريان درمان از يكديخر حمايت مى كنتـد، بـهـ

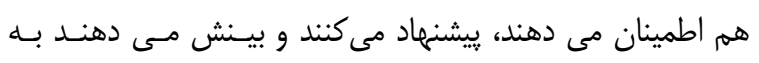
همين دليل اغلب سالمندان در اثر خــوش كـردن بـهـ سـاير افـراد كروه، با مشاهده ى آنها به شاخص هايى مى رسند كه از درمانكر نمى كَيرند. در مجموع به نظر مسى رســــــاربرد ايـن روش بـــ لحاظبالينى سودمند و اثربخش و از لحـاظ اقتصـادى مقــرون بــــ صرفه و قابل توصيه است (1). به طور كلى نتايج مطالعهى حاضر نشان داد كه درمانخرى مبتنى بر يذيرش و تعهل ميتواند احساس تنهايى را در سالمندان با سندرم اشيانه خالى كـاهش دهـــ و يِشــهاد ميشـود متخصصـان حـوزه سلامت در كنار ساير رويكردهاى رواندرمانى به روشهاى درمـانى جديدتر از جمله درمان مبتنى بر يذيرش و تعهد و درمان مبتنى بـر شفقت كه در كاهش احساس تنهايى سالمندان مـؤثر هسـتند نيـز

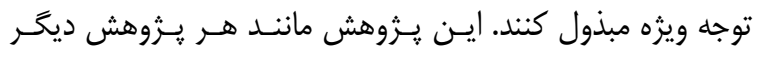
محدوديتهايى از جمله محدوديت در روايى بيرونى داشت. همجنين مى توان به عدم انجام مرحله يِيَيرى و در دسترس بـودن جامعـه
بخشيدن به زندگى و نه كميت آن كنند و با نگاهى خوشبينانه به آينده، تعيين اهداف، ارزشها و طـرحريـزى برنامـهـــاى جديـــــر زندگى جرأت روبلرو شدن صادقانه و حقيقى بـا زنـدكى را ييـدا كنند. ميتوان كفت آكاهى و درى جديدتر و عميقترى كه بـراى

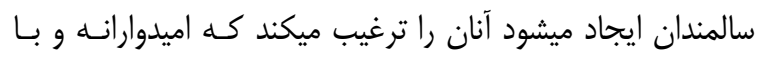

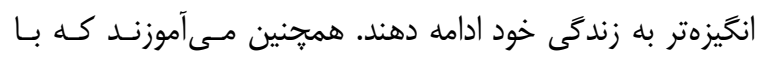
تمركز نكردن به زمان و هُكونكَى مرك خود زندكى هدفمنـدترى

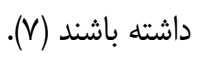

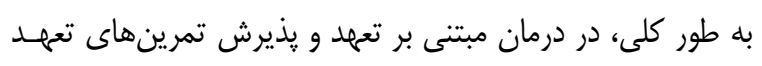
رفتارى به همراه تكنيكهاى كسلش و يذيرش و نيـز بحـثهـاى مفصل ييرامون ارزشها و اهداف فرد و لزوم تصريح ارزشها، منجـر به كاهش احساس تنهايى در سالمندان شد. در اين درمان، هدف از تأكيد بسيار بر تمايل افراد به تجربههاى درونى، كمى به افراد در راستاى تجربه كردن افكار آزار دهندهشان صرفاً به عنوان يك فكر و انجام امور مهم زندكيشان در راستاى ارزشهايشان بـود؛ در ايـن درمان، با جايخزين كردن خود به عنوان زمينه، مراجعان توانسـتند رويدادهاى درونى ناخوشايند را در زمان حال به سادگى تجربه كنند و قادر به جدا كردن خود از واكنشها، خـاطرات و افكـار ناخوشـايند شدند. در واقع در فرآيند اين درمان، به سالمند آموزش داده شد كه جَكَونه از افكار آزاردهنده رهايى يابند، به جاى خود مفهـومسـازى شده، خود مشاهدهر را تقويت نمايند، رويدادهاى درونى را به جاى كنترل كردن بيذيرند، ارزشهايشان را تصريح كنند و به آنها بيردازند

نكته مهم دركاربرد اين روش اين است كه روش گروهى محاسن فراوانى دارد كه منجر به تسهيل وتسريع فرايند درمان مى شود. از جمله اينكه بسيارى از سالمندان با سندرم آشيانه خالى بــه نـوعى لـ 


$$
\begin{aligned}
& \text { آمارى اشاره كرد كه در تعميم نتايج بايد جانب احتياط رعايت شود. تشكر و قدردانى } \\
& \text { علاوه بر آن با توجه به يافته هاى اين تحقيق كه نشان داد درمان يزوهشگران خود را موظف مى دانند به رسم امانتدارى علمى و به }
\end{aligned}
$$

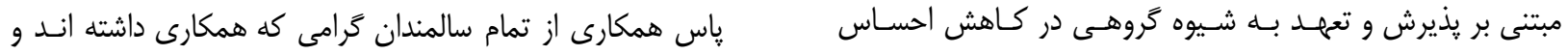

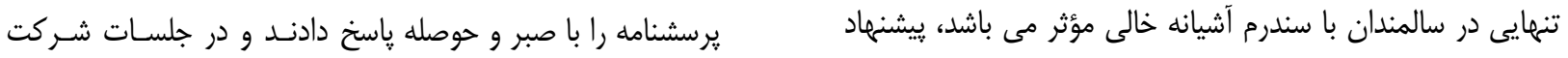

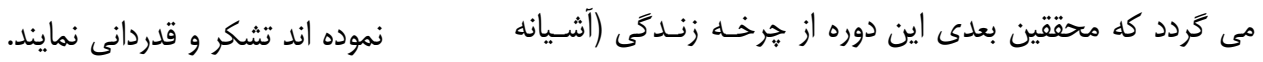

$$
\begin{aligned}
& \text { خالى) را نيز موضوع مطالعه خود قرار دهند و به ارتقـاى سـلامت } \\
& \text { روان و سطح زندگى آنان همت گمارند. }
\end{aligned}
$$

\section{- References}

1. Damirchi Sadri A, Ramezani Sh. The effectiveness of treatment on loneliness and anxiety of death in the elderly. Journal of Psychology Aging. 2016; 2 (1): 1-12. (Persian).

2. Khaledian M, Sohrabi F. The effectiveness of sense therapy on depression and hope in the elderly with the syndrome of Empty Nest. Journal of Clinical Psychology.2014. 15 (4): 79-103. (Persian).

3. Kaisa E, Sirpa H, Irma N. Is Loneliness Associated with Malnutrition in Older People? International Journal of Gerontology. 2016; 10(1): 43-45.

4. Leibing A, Guberman N, Wiles J. Liminal homes: Older people, loss of capacities, and the present future of living spaces. Journal of Aging Studies. 2016; 37(2): 10-19.

5. Zhou Ch, Chunmei Ji, Jie Chu, Alexis Medina, Cuicui Li, Shan Jiang, Wengui Zheng, Jing Liu, Scott Rozelle. Non-use of health care service among empty-nest elderly in Shandong, China: a cross-sectional study. BMC Health Serv Res. 2015; 15: 294. Published online 2015 Jul 29. doi: 10.1186/s12913-015-0974-1

6. Fakhri F.R, Hashemi M.A. A Qualitative Research: Postmenopausal Women's Experiences of Abuse. Procedia-Socialand Behavioral Sciences. 2013; 82: 57-60. (Persian).

7. Yang T, Chu J, Zhou C, Medina A, Li C, Jiang S, Zheng W, Sun L, Liu J. Catastrophic health expenditure: a comparative analysis of empty-nest and non-empty-nest households with seniors in Shandong, China. BMJ Open. 2016; 5-6(7):e010992. doi: 10.1136/bmjopen-2015-010992.

8. Duvall E.M. Marriage and family development (5th ed). New York: Lippincott.1997. P: 65-66. 
9. Khaledian M, Gharibi H, gholizadeh K, Shakeri R. The effectiveness of cognitive - behavioral depression and life expectancy empty nest syndrome. Journal of Counseling and Psychotherapy family. 2013; 2: 261-279 (Persian).

10. Momeni $\mathrm{Kh}$. The effectiveness of integrative reminiscence and narrative reducing the symptoms of depression in elderly women living in nursing homes. Journal of Consulting and family psychotherapy.2011; 1 (3): 361-388 (Persian).

11. Whelen S. M, Heather B, Michelle Feltz R, Whelen M. Loneliness among People with Spinal Cord Injury: Exploring the Psychometric Properties of the 3-item Loneliness Scale. Archives of Physical Medicine and Rehabilitation. 2016; 97(10): 1728-1734.

12. Routasalo P.E, Savikko N, Tilvis R.S, Strandberg T.E, Pitkala K.H. Social contacts and their Relationship to Loneliness among people- a population Based study. Gerontology. 2006; 52(2): 181-187.

13. Chiang K.J, Chu H, Chang H.J, Chung M.H, Chen C.H, Chiou H.G, Chou K.R. The effect of reminiscence therapy on psychological well-being, depression, and loneliness among the institutionalized aged. Journal of geriatric psychiatry. 2009; 25(4): 380-388.

14. Fakhar F, Navabinejad Sh, Foroughan M. The effect of group counseling therapy approach on the mental health of older women. Iranian Journal of Ageing. 2008; 7 (3): 58-67. [Persian].

15. Mclnnis G. J, White J. H. A phenomenological Exploration of Loneliness in the older Adult. Archives of psychiatric Nursing. 2001; 20(3): 128-139.

16. Abitov Ildar R, Gorodetskaya Inna M. Self-Regulation and Experience of Loneliness of Elderly People Who Live in Social Care Residences. International Journal of Environmental and Science Education. 2016; 11(6): 1021-1029.

17. Werner S, Dimitris M. The lost Gemeinschaft: How people working with the elderly explain loneliness. Journal of Aging Studies. 2015; 33(2): 1-10.

18. Luo Y, Waite L. J. Loneliness and Mortality among Older Adults in China. The Journals of Gerontology Series B: Psychological Sciences and Social Sciences. 2014; 69(4): 633-645.

19. Alpass F. M, Neville S. Loneliness, Health and Depression in older males. Journal Aging \& Mental health. 2010; 7(23), 212-216.

20. Vallis M, Ruggiero L, Greene G, Jones H, Zinman B, Rossi S, ... Prochaska J. O. Stages of change for healthy eating in diabetes: Relation to demographic, eating-related, health care utilization, and psychosocial factors. Diabetes Care. 2003; 2(5): 468-474.

21. Hayes S.C, Luoma J.B, Bond F.W, Masuda A, Lillis J. Acceptance and commitment therapy: Model, processes and outcomes. Behaviour Research and Therapy. 2006; 44(1): 1-25. 
22. Forman E.M, Herbert D. New directions in cognitive behavior therapy: Acceptance based therapies, chapter to appear. In W. T. O'Donohue, J. E. Fisher, (Eds.), Cognitive behavior therapy: Applying empirically supported techniques in your practice. 2009. P: 198-9(2nd ed.). Hoboken, NJ: John Wiley \& Sons.

23. Kakavand A.R, Baqeri M.R, Shirmohamadi F. The Effectiveness of Acceptance and Commitment Therapy on Stress Reductionin Afflicted Elderly Men to Heart Diseases. Journal of Aging Psychology. 2016, 1(3): 169-178. (Persian).

24. Izadi R, Abedi M. Acceptance and Commitment Therapy. Tehran: Jungle.2013.P:1-210 (Persian).

25. Dehshiri Gh.R, Borjali A, Sheikhi M, Habibi Askarabadi M. Construction and Validation of a Scale loneliness among students. Psychology Quarterly. 2008; 12 (47): 282-296. [Persian].

26. Dahl C, Stuart A, Martel K, Kaplan C. ACT and RFT in relationships: helping clients eager for intimacy and maintain healthy obligations. Translation: Navabinejad Sh, Saadati N. and Rostami M. The first edition, Tehran: the Jungle.2015.P:1-297. (Persian).

27. Henrich L.M, Gullone E. The clinical significance of loneliness: a literature review. Clinical Psychology Review. 2006; 26(1): 695-718.

28. Sadock B.J, Sadock V.A. Kaplan \& Sadock's Synopsis of Psychiatry. Lippincott Wilkins: Wolters Kluwer.2007.P: 120-3. 